\title{
Long-Run Retail Interest Rate Pass-Through In The Euro Area: The Effect Of The Financial Crisis
}

\author{
Manel Mansour, University of Monastir, Tunisia \\ David Heller, ISC Paris, France \\ Moez Labidi, University of Monastir, Tunisia \\ Amine Lahiani, Laboratoire d'Economie d'Orléans, France
}

\begin{abstract}
This paper analyzes the long-run pass-through of money market rates to retail interest rates (both lending and deposit rates). We rely on fully harmonized data from MIR statistics (MFI Interest Rates) for 8 countries of the euro area. From January 2003 to February 2014, interest rates are observed on a monthly basis on new contracts related to the three largest segments of the banking market (consumer, mortgage, and Non-Financial Corporations - NFCs). The long-term passthrough is measured following the Phillips and Loretan (PL) approach which is proved to be more effective than the Engle-Granger OLS (EG-OLS) approach. We also investigate the effect of the financial crisis on the degree of the long-run pass-through. Results suggest that the financial crisis deepens the heterogeneity of the speed and degree of the bank rates adjustment mechanism. Moreover, within the same country, the characteristics of long-run pass-through differ both among banking products and time horizon.
\end{abstract}

Keywords: Retail Interest Rates; Money Market Rates; Euro Area; Phillips And Loretan Approach; Long-Term Pass-Through

\section{INTRODUCTION}

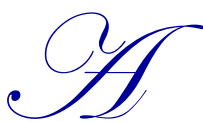

crisis in the United States sets off a crisis in Europe and consequently engulfs the whole world. Indeed, following the subprime crisis that began in 2007 and exploded in September 2008, the turbulence began spreading to European financial markets leading to a general loss of confidence because banks have become more reluctant to lend money to other banks in the interbank market. Consequently, a shortage of liquidity in the money market and an increased demand for liquidity from the European Central Bank (ECB) are recorded. The increase in the long-term Money Market Rate (MMR) reflects the increasing uncertainty about the reliability of counterpart banks (Aristei and Gallo, 2012). Faced with this crisis, the ECB increased the liquidities attributed with its long-term refinancing operations (LTRO). In addition, to support the increased demand for foreign currency liquidity the ECB provided dollar liquidity by the "Term Auction Facility" operations (Abbassi and Linzert, 2012; Cecion et al., 2011).

As a result of this crisis, the U.S. investment bank "Lehman Brothers" has fallen into bankruptcy in September 15, 2008; which further exacerbated the situation by increasing the credit risk on the interbank market. This prompted the ECB to lower its policy rate several times and adopt unconventional measures. Indeed, in October 2008, the ECB conducted refinancing operations with fixed rate call for bids and expanded the list of eligible collateral. In addition, it continued to provide foreign currency liquidity.

In order to decrease the impact of the sovereign debt crisis on the transmission mechanism of monetary policy, a program for securities markets (Securities Market Program - SMP) was established in May 10, 2010. It allows the Eurosystem to intervene in the secondary bond markets in the euro area by purchasing private and public 
securities aiming at boosting the functioning of certain government bond markets affected by the increase of public deficit in some European countries. On the other hand, most of the purchases under the SMP were made during the first weeks after its implementation and systematically sterilized through specific operations of reabsorption of the injected liquidities (Cordemans and Perea, 2011). In general terms, when the financial crisis, and more recently the crisis of public debt, affected the rates of money and bond markets, they indirectly influenced the lending and deposit rates offered by banks to households and firms. Indeed, bank rates in the euro area have evolved to varying degrees due to changes in MMR.

The current empirical literature on interest rate pass-through has two main shortcomings. First, it fails to take into account the effect of a change in the expected future market rates when seeking the relationship between long-term bank rates and market rates. For instance, the Engle and Granger approach (1987), which is widely used in this context. Unfortunately, it does not allow drawing the degree of long-term pass-through using the theory of standard distribution. The contribution of this article to the existing literature on long-run pass-through of market rates to bank rates is twofold. On the one hand, it analyzes the transmission mechanism of monetary policy by using the methodology of Phillips and Loretan (1991) (PL) to estimate the degree of pass-through to bank rates in the euro area. Indeed, this method includes the effect of the dynamics i.e. past and future changes in the MMR in modeling long-term pass-through. On the other hand, it captures the effects of the financial crisis on the degree of passthrough over a longer period than previous studies, while still using harmonized data.

This study revolves around the following structure. In section 2, we review the empirical literature related to the impact of the financial crisis on the transmission mechanism of policy rates to bank rates. Then, in section 3, we present the econometric methodology we adopt. In section 4, we present the data and discuss the results provided by the PL approach. Section 5 presents the impact of the financial crisis on the degree of the long-run pass-through. Section 6 concludes and presents some policy recommendations.

\section{LITERATURE REVIEW}

There is a vast literature on the pass-through of interest rates, which was expanded after the global financial crisis. In considering whether the crisis has changed the transmission of interest rate, Jobst and Kwapil (2008) study the long-term pass-through to lending rates in Austria and cannot detect striking differences in the process of passthrough from the beginning of the financial crisis. In addition, according to the Bundesbank (2009) and ECB (2009) the transmission from MMR to lending rates and deposit rates works relatively well during the financial crisis even when banks tightened their credit supply. However, for the European Monetary Market (EMU) Cihak et al. (2009) suggest a slower short-term pass-through during the crisis. Similarly, Karagiannis et al. (2010) notice that there is a widening of the spread between MMR and bank rates at the beginning of the financial crisis i.e. the long- and shortterm pass-through has been limited to some extent.

In addition, Belke et al. (2013) investigate the monetary transmission process in the euro area between 2003 and 2011 and find considerable differences in the degree of long- and short-run pass-through with regard to the different rates on either loans or countries. In most cases, they concluded that the pass-through is incomplete and the dynamics of adjusting loans are different because of the fluctuations in the MMR. In addition, Blot and Labondance (2013) demonstrate that the heterogeneity of the degree of short- and long-term interest rate pass-through between the euro area member States was more pronounced following the financial crisis.

Ritz (2010) shows that banks with a solid base of deposits appear stronger throughout the financial crisis. Indeed, the increase in the uncertainty of funding can explain more intense competition for deposits and generally amortized pass-through from market interest rates to bank rates. These results may help explain some of the behavior of commercial banks (e.g following the decline in MMR, banks do not act immediately to incorporate this change in their rates) and the reduced effectiveness of monetary policy during the 2007- 2009 financial crisis.

Gambacorta and Marques-Ibanez (2011) argue that the bank specific characteristics may have a significant impact on allocating loans. These Characteristics include changes in business patterns and bank funding models which modify the money transmission mechanism. Banks with lower fund positions and consequently with a greater reliance on market funding and income of non-interest sources curb the supply of loans more strongly during the 
crisis period. On the other hand, Cordemans and Sola Perea (2011), focusing on certain decisions adopting unconventional monetary policy in the euro area (unlimited provision of liquidity, long-term refinancing operations, purchasing of covered bonds and the securities markets program), note that although the purpose of these measures was to preserve the proper functioning of the monetary transmission mechanism, some of these measures have led to a further decline in interest rates.

Outside the euro area, Hansen and Welz (2011) study the impact of changes in interest rates of the Swedish central bank - the Riksbank- on the MMR rate and on the rates proposed by financial institutions to their customers both before and during the financial crisis. They conclude that the MMR transmission channel of rates offered by financial institutions has been preserved for short maturities, but weakened for long maturities. This phenomenon could be explained by lack of access to long-term funding.

\section{Econometric Methodology}

There are two approaches to estimate the pass-through of interest rates: the cost approach and the fund approach to monetary policy. In this paper we will refer to the latter approach, which controls for the relationship between MMR and bank rates. This relationship can be explained using the model of marginal cost prices (De Bondt, 2005). Hence, the price is equal to marginal cost and the derivative of price relative to the marginal cost is equal to 1, but it becomes less than unity if the information price is incomplete (see Tai and al., 2012).

So, in order to estimate the long-term relationship between banks interest rates and reference market rates, we adopt the following equation:

$$
B R_{t}=\alpha_{0}+\propto_{1} \mathrm{MMR}_{\mathrm{t}}+\varepsilon_{t}
$$

with $B R_{t}$ refers to either credit or deposit rates, $M_{\mathrm{m}} \mathrm{x}_{\mathrm{t}} \mathrm{y}_{\mathrm{t}}$ denotes thex $\mathrm{t}_{\mathrm{t}}$ corresponding money market rate and $\varepsilon_{t}$ is the error term.

MMR is the marginal cost of prices mostly adopted in the related literature thanks to its ability to reflect marginal cost of funds. $\alpha_{0}$ and $\alpha_{1}$ are the long-run coefficients. $\alpha_{0}$ is the profit margin and $\alpha_{1}$ measures the degree of pass-through from market rates to bank interest rates. The long-term pass-through is complete if $\alpha_{1}$ is statistically equal to 1 . But if $0<\alpha_{1}<1$, the pass-through is incomplete. This implies that the elasticity of demand to deposits and borrowings is incomplete and also banks have some degree of market power.

Equation (1) can be estimated using the Engle and Granger Ordinary Least Squares (EG-OLS) procedure and provides a consistent estimate of the pass-through coefficient provided that the two sets of non-stationary interest rates are cointegrated. The problem with the EG-OLS is that the statistical tests of the OLS estimation of equation (1) do not have asymptotically standard distributions. Therefore, we use the PL approach, that we introduce in the following paragraph, for the subsequent analysis.

While comparing the PL-approach to the EG-OLS procedure, we find that the PL estimator is asymptotically unbiased and normally distributed and proved to perform well in finite samples. In contrast, the EGOLS estimator, despite being consistent, has two limitations: first, it is biased in finite sample and this can lead to an incorrect assessment of the effectiveness of monetary policy mechanism and hence serious miscalculations policy. For example, if the degree of pass-through is underestimated the policy may be excessively tight in the fight against inflationary pressures, resulting in serious bad consequences for growth and employment (Liu et al, 2008). Second, the distribution of the EG-OLS estimator is not asymptotically normal, which makes it difficult to draw meaningful statistical inferences from long-term coefficients, even in very large samples. These two problems are avoided by applying the PL approach. Indeed, this method includes the effect of the dynamics, i.e. past and future changes in the MMR, in modeling long-term pass-through. Past and future expectations of changes in the market rates are key determinants of bank interest rates. A further advantage of the PL approach is that it is adapted to situations where the long-term relationship between bank rates and market rates may be subject to structural changes. 
Furthermore, the PL method is well suited for estimating long-term relationships between cointegrated variables. The inclusion of lagged differences eliminates the problem of endogeneity and also the problem of autocorrelation can be corrected by the inclusion of the lag of the error correction term. Hence, Loretan and Phillips (1991) propose to estimate the following equation:

$$
\begin{aligned}
& \mathrm{RMM}_{\mathrm{t}}=\propto+\propto_{1} \mathrm{BR}_{\mathrm{t}}+\sum_{\mathrm{k}=1}^{\mathrm{K}} \mathrm{d}_{1 \mathrm{k}}\left(\mathrm{RMM}_{\mathrm{t}-\mathrm{k}}\right. \\
& B R_{t}=\propto_{0}+\propto_{1} M M R_{t}+\sum_{k=1}^{K} d_{1 k}\left(B R_{t-k}-\propto_{0}-\propto_{1} M M R_{t-k}\right)+\sum_{i=-l}^{L} d_{2 i} \Delta M M R_{t-i}+\vartheta_{1 t} \vartheta_{1 \mathrm{t}}
\end{aligned}
$$

They show that the estimated parameters are equivalent to those obtained by estimating a cointegrated VAR system via maximum likelihood. Thus, the parameter estimates are asymptotically unbiased and normally distributed.

\section{DATA AND RESULTS}

\section{Data Overview}

This paper investigates the long-run pass-through from market rates to bank rates using a sample of central banks of eight member countries of the Euro area namely the Bank of Germany (DE), Bank of Greece (GR), Bank of Spain (ES), Bank of France (FR), Bank of Italy (IT), National Bank of Austria (AT), Bank of Portugal (PT) and Bank of Finland (FI).

Interest rates are observed on new monthly contracts ${ }^{1}$ over the period spanning from January 2003 to February 2014 and include both credit and deposit rates. Among the lending rates we analyze the interest rates on consumer credit less than one year, the interest rates on short-term loans to non-financial corporation's (NFCs) for loans over one million Euros and the interest rate on mortgage loans of less than one year. Regarding deposit rates we consider the interest rates on deposits with agreed maturity from households for less than one year, the overnight interest rates on deposits from households and the overnight interest rates on deposits of NFCs. Reference Market rates are the 3-month Euribor (Euro Interbank Offered Rate) and the EONIA rate (Euro Overnight Index Average) for the overnight rates.

According to the figures presented in Appendix B, all bank rates follow a similar trajectory. In fact, each series witnesses four phases: a first phase of stability (zero trend) then a phase of rapid growth followed by a phase of a faster drop than that of growth and finally a fourth phase marked by a return to stability more or less characterized by a slight increase from 2010 . This can be explained by the diffusion of the sovereign debt crisis in Europe. However, the subprime crisis is eventually noticed in all graphs and results in a peak in September 2008.

Descriptive statistics of interest rates (see Tables1 and 2) show the heterogeneity between countries in terms of rates means and standard deviations. In average, the lending rates are higher than the deposit rates. More specifically, the mean credit consumption rates vary between 4.361 in Finland and 9.213 in Italy while for the household deposit rate with agreed maturity the mean is between 2.012 (for Italian rates) and 3.379 (for Greek rates). As regards the standard deviation it suggests similar results except for deposit rates where heterogeneity is clearer for the overnight deposit rate of NFCs.

Regarding the correlation (see tables presented in appendix C) between the bank rates and the money market rate, Greece stands out as the Greek credit rates to the consumer are negatively correlated with MMR. In contrast, other countries such as Austria and Finland show bank rates strongly correlated with MMR. Accordingly, the ability of monetary policy to manage the bank rates (lending and deposit) may differ significantly from one country to another and impulses of monetary policy will not be transmitted homogeneously across countries.

\footnotetext{
${ }^{1}$ Bank rates used in this paper are from the harmonized survey on interest rates of monetary financial institutions of the euro area (MFI Interest Rate - MIR). Data are available on a monthly basis since January 2003. This survey has replaced the RIR survey (Retail Interest Rate) which provided non harmonized bank rates statistics. As part of this analysis, we use new business rates to understand their changes over time. These synthetic rates correspond to weighted averages by outstanding rates applied by monetary and financial institutions in each country. However, the constraint for an ideal database for the empirical analysis of pass-through across countries is a short sample hinders for econometric exercises.
} 
Table 1. Descriptive statistics of lending rates and the corresponding MMR

\begin{tabular}{|c|c|c|c|c|c|c|c|c|c|c|c|c|}
\hline & \multicolumn{4}{|c|}{ Credit consumption rates } & \multicolumn{4}{|c|}{ Credit rates of NFC } & \multicolumn{4}{|c|}{ Mortgage credit rates } \\
\hline & Mean & $\begin{array}{l}\text { Standard } \\
\text { deviation }\end{array}$ & J-B & p-value & Mean & $\begin{array}{l}\text { Standard } \\
\text { deviation }\end{array}$ & J-B & p-value & Mean & $\begin{array}{l}\text { Standard } \\
\text { deviation }\end{array}$ & J-B & p-value \\
\hline ZEURO & 6.682 & 1.126 & 6.293 & 0.043 & 3.200 & 1.015 & 19.935 & 0.000 & 3.658 & 0.876 & 20.169 & 0.000 \\
\hline $\mathrm{DE}$ & 4.955 & 0.925 & 10.039 & 0.007 & 3.301 & 1.081 & 9.168 & 0.010 & 4.236 & 1.041 & 7.916 & 0.019 \\
\hline GR & 8.809 & 1.089 & 9.358 & 0.009 & 4.732 & 1.018 & 11.749 & 0.003 & 3.977 & 0.745 & 2.860 & 0.239 \\
\hline ES & 8.302 & 1.826 & 4.700 & 0.095 & 3.241 & 0.977 & 25.474 & 0.000 & 3.584 & 0.965 & 23.945 & 0.000 \\
\hline FR & 6.313 & 1.005 & 4.484 & 0.106 & 2.950 & 1.107 & 18.490 & 0.000 & 3.753 & 0.698 & 11.585 & 0.003 \\
\hline IT & 9.213 & 2.179 & 18.965 & 0.000 & 3.254 & 0.934 & 9.657 & 0.008 & 3.733 & 0.936 & 5.602 & 0.061 \\
\hline AT & 5.326 & 0.703 & 15.451 & 0.000 & 2.953 & 1.096 & 13.337 & 0.001 & 3.845 & 1.113 & 8.150 & 0.017 \\
\hline PT & 7.730 & 0.916 & 8.864 & 0.012 & 4.548 & 0.896 & 9.233 & 0.010 & 3.702 & 0.868 & 4.124 & 0.127 \\
\hline FI & 4.361 & 0.854 & 8.536 & 0.014 & 3.029 & 1.101 & 12.836 & 0.002 & 3.035 & 1.061 & 12.527 & 0.002 \\
\hline MMR & 2.049 & 1.426 & 9.740 & 0.008 & 2.049 & 1.426 & 9.740 & 0.008 & 2.049 & 1.426 & 9.740 & 0.008 \\
\hline
\end{tabular}

Table 2. Descriptive statistics of deposit rates and the corresponding MMR

\begin{tabular}{|c|c|c|c|c|c|c|c|c|c|c|c|c|}
\hline & \multicolumn{4}{|c|}{$\begin{array}{c}\text { Deposit rate with agreed maturity of } \\
\text { household }\end{array}$} & \multicolumn{4}{|c|}{ Overnight deposit rate of household } & \multicolumn{4}{|c|}{ Overnight deposit rates of NFC } \\
\hline & Mean & $\begin{array}{l}\text { Standard } \\
\text { deviation }\end{array}$ & $\mathbf{J}-\mathbf{B}$ & p-value & Mean & $\begin{array}{l}\text { Standard } \\
\text { deviation }\end{array}$ & $\mathbf{J}-\mathbf{B}$ & p-value & Mean & $\begin{array}{l}\text { Standard } \\
\text { deviation }\end{array}$ & $\mathbf{J}-\mathbf{B}$ & p-value \\
\hline ZEURO & 2.566 & 0.826 & 25.523 & 0.000 & 0.692 & 0.284 & 9.733 & 0.008 & 0.960 & 0.539 & 17.871 & 0.000 \\
\hline $\mathrm{DE}$ & 2.019 & 1.063 & 18.326 & 0.000 & 1.106 & 0.450 & 6.445 & 0.040 & 1.086 & 0.718 & 10.253 & 0.006 \\
\hline GR & 3.379 & 1.005 & 11.693 & 0.003 & 0.783 & 0.315 & 13.190 & 0.001 & 0.618 & 0.247 & 17.945 & 0.000 \\
\hline ES & 2.619 & 0.903 & 24.067 & 0.000 & 0.469 & 0.200 & 9.367 & 0.009 & 0.871 & 0.493 & 45.149 & 0.000 \\
\hline FR & 2.370 & 0.854 & 29.652 & 0.000 & 0.122 & 0.042 & 11.353 & 0.003 & 0.359 & 0.146 & 34.322 & 0.000 \\
\hline IT & 2.012 & 0.686 & 8.966 & 0.011 & 0.623 & 0.350 & 18.790 & 0.000 & 1.251 & 0.677 & 34.360 & 0.000 \\
\hline $\mathrm{AT}$ & 2.077 & 1.105 & 16.344 & 0.000 & 0.990 & 0.492 & 19.539 & 0.000 & 1.267 & 0.842 & 13.845 & 0.001 \\
\hline $\mathrm{PT}$ & 2.573 & 0.908 & 13.156 & 0.001 & 0.150 & 0.074 & 9.001 & 0.011 & 0.484 & 0.374 & 23.982 & 0.000 \\
\hline FI & 2.286 & 1.101 & 26.939 & 0.000 & 0.540 & 0.280 & 84.971 & 0.000 & 0.891 & 0.708 & 25.571 & 0.000 \\
\hline MMR & 2.049 & 1.426 & 9.740 & 0.008 & 1.739 & 1.366 & 10.166 & 0.006 & 1.734 & 1.362 & 10.244 & 0.006 \\
\hline
\end{tabular}

\section{Estimation Results Of Long-Term Pass-Through According To The PL Approach}

Tables 3 and 4 report the estimation results of the long-run pass-through from market rates to bank rates using the PL approach. Regarding lending rates, results clearly show that the pass-through of market rates to credit rates of NFC and Mortgages credit rate is more pronounced as compared to that of credit consumption rates and exceeds in some cases the pass-through of market rate to Euro Zone. For instance, the pass-through of money market rate to credit rates of NFC for Germany (0.331), France (0.325), Austria (0.347) and Finland (0.326) is higher than that to the Euro Zone (0.270). Similarly, the pass-through of money market rate to mortgage credit rate is higher for Germany (0.249), Austria (0.291) and Finland (0.324) than that to the Euro Zone (0.196) whereas the pass-through to Greece (0.196) and Spain (0.195) is similar to that to the Euro Zone (0.196). However, the passthrough of MMR to credit consumption rates is low for most countries except for Italy $(0.210)$ which is largely higher than that to the Euro Zone (0.131). Spain (0.132) and Finland (0.137) show a pass-through comparable to that to the Euro Zone (0.131). It is also worth noting that the long-term pass-through of MMR to lending rates is positive for all countries except the pass-through of MMR to credit rates of NFC in Greece. This may be due to the Greek sovereign debt crisis in 2012. 
Table 3. Estimation results of the long-run pass-through to lending rates by PL approach

\begin{tabular}{|c|c|c|c|c|c|c|}
\hline \multirow[t]{2}{*}{ Countries } & \multicolumn{2}{|c|}{ Credit consumption rates } & \multicolumn{2}{|c|}{ Credit rates of NFC } & \multicolumn{2}{|c|}{ Mortgage credit rate } \\
\hline & $\propto_{0}$ & $\propto_{1}$ & $\propto_{0}$ & $\propto_{1}$ & $\propto_{0}$ & $\propto_{1}$ \\
\hline Euro Zone & $\begin{array}{l}1.835 * * * \\
(458.617)\end{array}$ & $\begin{array}{l}0.131 * * * \\
(33.391)\end{array}$ & $\begin{array}{l}1.018 * * * \\
(291.078)\end{array}$ & $\begin{array}{l}0.270 * * * \\
(79.061)\end{array}$ & $\begin{array}{l}1.198 * * * \\
(670.358)\end{array}$ & $\begin{array}{l}0.196 * * * \\
(111.933)\end{array}$ \\
\hline Germany & $\begin{array}{l}1.554 * * * \\
(241.477)\end{array}$ & $\begin{array}{l}0.074 * * * \\
(11.729)\end{array}$ & $\begin{array}{l}1.016 * * * \\
(230.107)\end{array}$ & $\begin{array}{l}0.331 * * * \\
(76.619)\end{array}$ & $\begin{array}{l}1.318 * * * \\
(495.072)\end{array}$ & $\begin{array}{l}0.249 * * * \\
(95.561)\end{array}$ \\
\hline Greece & $\begin{array}{l}2.160 * * * \\
(422.347) \\
\end{array}$ & $\begin{array}{l}0.020 * * * \\
(4.003)\end{array}$ & $\begin{array}{l}1.557 * * * \\
(241.337) \\
\end{array}$ & $\begin{array}{l}-0.048 * * * \\
(-7.638) \\
\end{array}$ & $\begin{array}{l}1.287 * * * \\
(361.369)\end{array}$ & $\begin{array}{l}0.196^{* * *} \\
(55.861)\end{array}$ \\
\hline Spain & $\begin{array}{l}2.037 * * * \\
(209.693)\end{array}$ & $\begin{array}{l}0.132 * * * \\
(13.902)\end{array}$ & $\begin{array}{l}1.066^{* * *} * \\
(159.406)\end{array}$ & $\begin{array}{l}0.201 * * * \\
(30.830)\end{array}$ & $\begin{array}{l}1.173 * * * \\
(509.628) \\
\end{array}$ & $\begin{array}{l}0.195 * * * \\
(86.521)\end{array}$ \\
\hline France & $\begin{array}{l}1.817 * * * \\
(446.140) \\
\end{array}$ & $\begin{array}{l}0.035^{* * *} \\
(8.776) \\
\end{array}$ & $\begin{array}{l}0.900 * * * \\
(153.656)\end{array}$ & $\begin{array}{l}0.325 * * * \\
(56.750) \\
\end{array}$ & $\begin{array}{l}1.243 * * * \\
(562.538)\end{array}$ & $\begin{array}{l}0.163 * * * \\
(74.721)\end{array}$ \\
\hline Italy & $\begin{array}{l}2.106 * * * \\
(451.817) \\
\end{array}$ & $\begin{array}{l}0.210 * * * \\
(46.015)\end{array}$ & $\begin{array}{l}1.074 * * * \\
(170.373) \\
\end{array}$ & $\begin{array}{l}0.185 * * * \\
(30.095) \\
\end{array}$ & $\begin{array}{l}1.228 * * * \\
(560.084) \\
\end{array}$ & $\begin{array}{l}0.159 * * * \\
(74.322) \\
\end{array}$ \\
\hline Austria & $\begin{array}{l}1.626 * * * \\
(432.535) \\
\end{array}$ & $\begin{array}{l}0.105^{* * *} \\
(28.703)\end{array}$ & $\begin{array}{l}0.888 * * * \\
(176.985)\end{array}$ & $\begin{array}{l}0.347 * * * \\
(70.454)\end{array}$ & $\begin{array}{l}1.190 * * * \\
(320.262)\end{array}$ & $\begin{array}{l}0.291 * * * \\
(80.260)\end{array}$ \\
\hline Portugal & $\begin{array}{l}2.034 * * * \\
(672.632)\end{array}$ & $\begin{array}{l}0.015^{* * *} \\
(5.125)\end{array}$ & $\begin{array}{l}1.499 * * * \\
(279.081)\end{array}$ & $\begin{array}{l}0.005 \\
(1.037)\end{array}$ & $\begin{array}{l}1.231 * * * \\
(445.563)\end{array}$ & $\begin{array}{l}0.142 * * * \\
(52.844)\end{array}$ \\
\hline Finland & $\begin{array}{l}1.405 * * * \\
(397.085)\end{array}$ & $\begin{array}{l}0.137 * * * \\
(39.221)\end{array}$ & $\begin{array}{l}0.924 * * * \\
(96.778)\end{array}$ & $\begin{array}{l}0.326 * * * \\
(34.887)\end{array}$ & $\begin{array}{l}0.931 * * * \\
(427.534)\end{array}$ & $\begin{array}{l}0.324 * * * \\
(150.742)\end{array}$ \\
\hline
\end{tabular}

Note: This table shows the results of estimation results of Equation (2) for each lending rate following the PL approach. Values in parentheses express the $t$-statistic. $\left({ }^{* *}\right)\left({ }^{* *}\right)$ and $(*)$ indicate, respectively, significance at the $1 \%, 5 \%$ and $10 \%$ levels.

Results of the pass-through of MMR to deposit rates reported in table 4 show similar characteristics. Indeed, the pass-through is positive for all countries except for the pass-through to Deposit rates with agreed maturity of household in Greece. At the Euro Zone level the pass-through to deposit rates is higher than that to lending rates. Also the pass-through of MMR to deposit rates in European countries is higher than that to the Euro Zone. Indeed, for the deposit rate with agreed maturity five out of eight countries (Germany, Spain, France, Austria, Finland) show a higher pass-through than the pass-through to the Euro Zone. Similarly, five out of eight countries (Germany, Spain, Italy, Austria, Portugal, Finland) show a higher pass-through of MMR rate to overnight deposit rate of household. Furthermore, half of the considered European countries (Germany, Austria, Portugal, Finland) reveal a similar pattern of the pass-through of MMR to their overnight deposit rate of NFC. 
Table 4. Estimation results of the long-run pass-through to deposit rates by the PL approach

\begin{tabular}{|c|c|c|c|c|c|c|}
\hline \multirow[t]{2}{*}{ Countries } & \multicolumn{2}{|c|}{$\begin{array}{c}\text { Deposit rate with agreed } \\
\text { maturity of household }\end{array}$} & \multicolumn{2}{|c|}{$\begin{array}{c}\text { Overnight deposit rate } \\
\text { of household }\end{array}$} & \multicolumn{2}{|c|}{$\begin{array}{l}\text { Overnight deposit } \\
\text { rate of NFC }\end{array}$} \\
\hline & $\propto_{0}$ & $\propto_{1}$ & $\propto_{0}$ & $\propto_{1}$ & $\propto_{0}$ & $\propto_{1}$ \\
\hline Euro Zone & $\begin{array}{l}0.835 * * * \\
(151.309)\end{array}$ & $\begin{array}{l}0.167 * * * \\
(30.719)\end{array}$ & $\begin{array}{l}-0.450 * * * \\
(-179.745)\end{array}$ & $\begin{array}{l}0.300^{* * *} \\
(149.435)\end{array}$ & $\begin{array}{l}-0.188 * * * \\
(-63.258)\end{array}$ & $\begin{array}{l}0.394 * * * \\
(168.004) \\
\end{array}$ \\
\hline Germany & $\begin{array}{l}0.379 * * * \\
(50.097)\end{array}$ & $\begin{array}{l}0.506 * * * \\
(68.352)\end{array}$ & $\begin{array}{l}0.014 * * * \\
(5.823)\end{array}$ & $\begin{array}{l}0.321 * * * \\
(158.140)\end{array}$ & $\begin{array}{l}-0.195 * * * \\
(-49.376)\end{array}$ & $\begin{array}{l}0.626^{* * *} \\
(199.358)\end{array}$ \\
\hline Greece & $\begin{array}{l}1.181 * * * \\
(356.412)\end{array}$ & $\begin{array}{l}-0.019 * * * \\
(-5.669)\end{array}$ & $\begin{array}{l}-0.332 * * * \\
(-86.055)\end{array}$ & $\begin{array}{l}0.298 * * * \\
(99.046)\end{array}$ & $\begin{array}{l}-0.554 * * * \\
(-75.343)\end{array}$ & $\begin{array}{l}0.222 * * * \\
(39.022)\end{array}$ \\
\hline Spain & $\begin{array}{l}0.820 * * * \\
(144.704)\end{array}$ & $\begin{array}{l}0.229 * * * \\
(40.669)\end{array}$ & $\begin{array}{l}-0.861 * * * \\
(-152.221)\end{array}$ & $\begin{array}{l}0.321 * * * \\
(73.577)\end{array}$ & $\begin{array}{l}-0.260 * * * \\
(-41.694)\end{array}$ & $\begin{array}{l}0.311 * * * \\
(63.657)\end{array}$ \\
\hline France & $\begin{array}{l}0.711^{* * *} \\
(119.001)\end{array}$ & $\begin{array}{l}0.264 * * * \\
(45.246)\end{array}$ & $\begin{array}{l}-2.156^{* * *} \\
(-257.654)\end{array}$ & $\begin{array}{l}0.211^{* * *} \\
(32.380)\end{array}$ & $\begin{array}{l}-1.085^{* * *} \\
(-143.323)\end{array}$ & $\begin{array}{l}0.191 * * * \\
(32.492)\end{array}$ \\
\hline Italy & $\begin{array}{l}0.624 * * * \\
(110.595)\end{array}$ & $\begin{array}{l}0.061 * * * \\
(11.040)\end{array}$ & $\begin{array}{l}-0.618^{* * * *} \\
(-164.083)\end{array}$ & $\begin{array}{l}0.349 * * * \\
(119.239)\end{array}$ & $\begin{array}{l}0.098 * * * \\
(22.297)\end{array}$ & $\begin{array}{l}0.240 * * * \\
(70.268)\end{array}$ \\
\hline Austria & $\begin{array}{l}0.387 * * * \\
(89.333)\end{array}$ & $\begin{array}{l}0.542 * * * \\
(126.665)\end{array}$ & $\begin{array}{l}-0.121 * * * \\
(-25.123)\end{array}$ & $\begin{array}{l}0.336^{* * *} \\
(88.101)\end{array}$ & $\begin{array}{l}-0.005 \\
(-1.193)\end{array}$ & $\begin{array}{l}0.548 * * * \\
(159.887)\end{array}$ \\
\hline Portugal & $\begin{array}{l}0.838 * * * \\
(159.761)\end{array}$ & $\begin{array}{l}0.145 * * * \\
(28.304)\end{array}$ & $\begin{array}{l}-2.038 * * * \\
(-174.023)\end{array}$ & $\begin{array}{l}0.338 * * * \\
(37.220)\end{array}$ & $\begin{array}{l}-1.041 * * * \\
(-81.038)\end{array}$ & $\begin{array}{l}0.594 * * * \\
(59.762)\end{array}$ \\
\hline Finland & $\begin{array}{l}0.573 * * * \\
(113.451)\end{array}$ & $\begin{array}{l}0.415 * * * \\
(84.028)\end{array}$ & $\begin{array}{l}-0.713 * * * \\
(-129.878)\end{array}$ & $\begin{array}{l}0.242 * * * \\
(56.315)\end{array}$ & $\begin{array}{l}-0.435 * * * \\
(-72.644)\end{array}$ & $\begin{array}{l}0.634 * * * \\
(136.322)\end{array}$ \\
\hline
\end{tabular}

Note: This table shows the estimation results of Equation (2) for each deposit rate following the PL approach. Values in parentheses express the $t$-statistic. $(* * *)(* *)$ and $(*)$ indicate, respectively, significance at the $1 \%, 5 \%$ and $10 \%$ levels.

\section{IMPACT OF THE FINANCIAL CRISIS ON THE LONG-TERM PASS-THROUGH}

\section{Results of the Structural Break Test}

Figure 1 below depicts the evolution of the 3-month Euribor and EONIA money market rates from January 2003 to February 2014. The graph shows a break in the dynamic of the two previous rates in 2008 which corresponds to the Lehman Brothers bankruptcy. This break date is confirmed statistically using the Chow (1960) test. Indeed, results in Table 7 show that the test rejects the null of no break in September 2008 for all countries considered in this paper.

Figure 1. Evolution of EONIA and 3-month Euribor rate since 2003

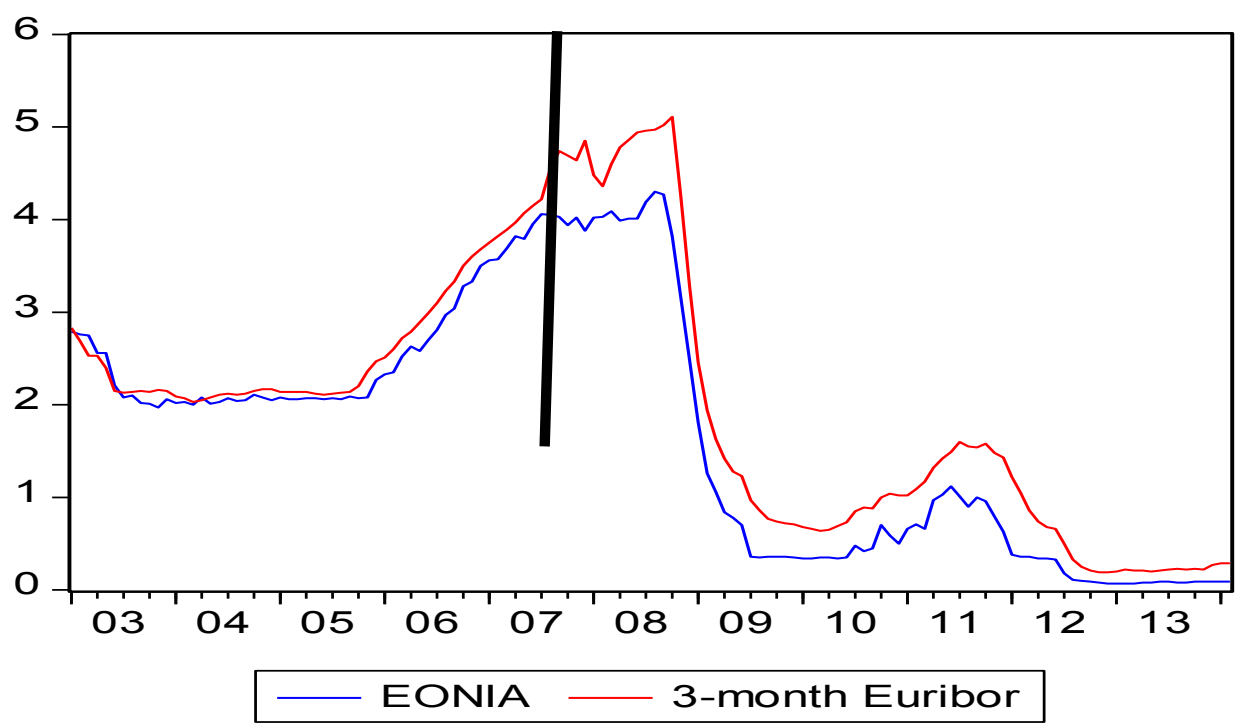


Table 5. Chow's break test in September 2008

\begin{tabular}{|c|c|c|c|c|c|c|}
\hline Countries & $\begin{array}{c}\text { Consumption } \\
\text { credit rate }\end{array}$ & $\begin{array}{l}\text { Credit rate } \\
\text { of NFC }\end{array}$ & $\begin{array}{l}\text { Mortgage } \\
\text { credit rate }\end{array}$ & $\begin{array}{l}\text { Deposit rate with agreed } \\
\text { maturity of household }\end{array}$ & $\begin{array}{l}\text { Overnight deposit } \\
\text { rate of household }\end{array}$ & $\begin{array}{l}\text { Overnight deposit } \\
\text { rate of NFC }\end{array}$ \\
\hline Euro Zone & $\begin{array}{l}9.352 * * * \\
(0.000)\end{array}$ & $\begin{array}{l}74.662 * * * \\
(0.000)\end{array}$ & $\begin{array}{l}51.253 * * * \\
(0.000)\end{array}$ & $\begin{array}{l}110.803^{* * *} \\
(0.000)\end{array}$ & $\begin{array}{l}28.798 * * * \\
(0.000)\end{array}$ & $\begin{array}{l}64.003 * * * \\
(0.000)\end{array}$ \\
\hline Germany & $\begin{array}{l}40.389 * * * \\
(0.000)\end{array}$ & $\begin{array}{l}86.930 * * * \\
(0.000)\end{array}$ & $\begin{array}{l}28.581^{* * * *} \\
(0.000)\end{array}$ & $\begin{array}{l}44.004 * * * \\
(0.000)\end{array}$ & $\begin{array}{l}26.057^{* * * *} \\
(0.000)\end{array}$ & $\begin{array}{l}25.838^{* * *} \\
(0.000)\end{array}$ \\
\hline Greece & $\begin{array}{l}30.258 * * * \\
(0.000)\end{array}$ & $\begin{array}{l}47.617 * * * \\
(0.000)\end{array}$ & $\begin{array}{l}6.894 * * * \\
(0.001)\end{array}$ & $\begin{array}{l}91.109 * * * \\
(0.000)\end{array}$ & $\begin{array}{l}31.174 * * * \\
(0.000)\end{array}$ & $\begin{array}{l}54.000 * * * \\
(0.000)\end{array}$ \\
\hline Spain & $\begin{array}{l}5.040^{* * *} \\
(0.008)\end{array}$ & $\begin{array}{l}62.478^{* * * *} \\
(0.000)\end{array}$ & $\begin{array}{l}49.927 * * * \\
(0.000)\end{array}$ & $\begin{array}{l}128.073^{* * *} \\
(0.000)\end{array}$ & $\begin{array}{l}2.250^{* * *} \\
(0.110)\end{array}$ & $\begin{array}{l}149.738^{* * *} \\
(0.000)\end{array}$ \\
\hline France & $\begin{array}{l}207.137 * * * \\
(0.000)\end{array}$ & $\begin{array}{l}51.521 * * * \\
(0.000)\end{array}$ & $\begin{array}{l}36.358^{* * *} \\
(0.000)\end{array}$ & $\begin{array}{l}65.179^{* * *} \\
(0.000)\end{array}$ & $\begin{array}{l}10.645^{* * *} \\
(0.000)\end{array}$ & $\begin{array}{l}89.904^{* * *} \\
(0.000)\end{array}$ \\
\hline Italy & $\begin{array}{l}17.542 * * * \\
(0.000)\end{array}$ & $\begin{array}{l}30.843 * * * \\
(0.000) \\
\end{array}$ & $\begin{array}{l}34.380^{* * * *} \\
(0.000)\end{array}$ & $\begin{array}{l}26.657^{* * * *} \\
(0.000)\end{array}$ & $\begin{array}{l}33.721^{* * * *} \\
(0.000)\end{array}$ & $\begin{array}{l}34.430 * * * \\
(0.000)\end{array}$ \\
\hline Austria & $\begin{array}{l}36.775^{* * *} \\
(0.000)\end{array}$ & $\begin{array}{l}49.967^{* * *} \\
(0.000)\end{array}$ & $\begin{array}{l}9.900^{* * *} \\
(0.000)\end{array}$ & $\begin{array}{l}47.143^{* * *} \\
(0.000)\end{array}$ & $\begin{array}{l}67.306^{* * * *} \\
(0.000)\end{array}$ & $\begin{array}{l}35.524^{* * *} \\
(0.000)\end{array}$ \\
\hline Portugal & $\begin{array}{l}8.209 * * * \\
(0.000)\end{array}$ & $\begin{array}{l}59.929 * * * \\
(0.000)\end{array}$ & $\begin{array}{l}18.452 * * * \\
(0.000)\end{array}$ & $\begin{array}{l}63.364 * * * \\
(0.000)\end{array}$ & $\begin{array}{l}14.503 * * * \\
(0.000)\end{array}$ & $\begin{array}{l}19.681 * * * \\
(0.000)\end{array}$ \\
\hline Finland & $\begin{array}{l}26.446 * * * \\
(0.000)\end{array}$ & $\begin{array}{l}37.706^{* * *} \\
(0.000)\end{array}$ & $\begin{array}{l}45.877 * * * \\
(0.000)\end{array}$ & $\begin{array}{l}106.272 * * * \\
(0.000)\end{array}$ & $\begin{array}{l}107.874 * * * \\
(0.000)\end{array}$ & $\begin{array}{l}135.073 * * * \\
(0.000)\end{array}$ \\
\hline
\end{tabular}

Note: This table shows the results of the Chow test (p-value). The null hypothesis is the absence of a break in September 2008. $* * *$ indicates rejection of the null at the $1 \%$ level.

With regard to these results, we divide the full sample period into two subperiods namely pre- and postcrisis periods. We then carry out estimation (2) in each of the subperiods.

\section{Subsample Analysis Using The PL Approach}

Respective estimation results of the long-term pass-through of money market rates to credit and deposit rates are reported in Table 6 . Overall, all the coefficients are highly significant. We also notice that the impact of the financial crisis is noteworthy on the degree of pass-through to consumer loan rates because the transmission has increased since the financial crisis in most member States of the euro area.

Pre-crisis values of PL estimation of the degree of transmission to consumption credit rates are higher for most countries. Accurate estimation of the degree of pass-through is of extreme importance for many reasons. For example, by underestimating the degree of pass-through, the monetary authority may unnecessarily tighten monetary conditions in an attempt to curb inflationary pressures. This action may exert unnecessary pressure on the real sector of the economy that causes jeopardizing growth and employment.

After the crisis, the comparison of the degrees of pass-through to lending rates reveals that rates on loans to NFCs recorded the highest degree of pass-through. Before 15 September 2008, the transmission from the 3-month Euribor rate to NFC credit rate is higher in many countries of the euro area.

Observing the results of the transmission to rates on mortgage loans, they show that during the financial crisis the degree of long-run pass-through has declined overall in the euro area, but Greece is an exception with a growing level of long-term pass-through following the market turmoil. Overall, results show that the degree of long-term pass-through is high before the crisis and low afterwards. 
Table 6. Pre- and post-crisis estimation results of pass-through from the 3-month Euribor to lending rates using the PL approach

\begin{tabular}{|c|c|c|c|c|c|c|}
\hline \multirow[t]{2}{*}{ Countries } & \multicolumn{2}{|c|}{ Consumption credit rate } & \multicolumn{2}{|c|}{ Credit rate of NFC } & \multicolumn{2}{|c|}{ Mortgage credit rate } \\
\hline & BC & AC & BC & AC & BC & AC \\
\hline Euro Zone & $\begin{array}{c}0.270 * * * \\
(21.493)\end{array}$ & $\begin{array}{c}0.073 * * * \\
(9.309)\end{array}$ & $\begin{array}{c}0.703 * * * \\
(114.588)\end{array}$ & $\begin{array}{c}0.184 * * * \\
(23.947)\end{array}$ & $\begin{array}{l}0.543 * * * \\
(140.853)\end{array}$ & $\begin{array}{c}0.141^{* * *} \\
(35.557)\end{array}$ \\
\hline Germany & $\begin{array}{c}0.219 * * * \\
(12.948)\end{array}$ & $\begin{array}{c}-0.101 * * * \\
(-7.597)\end{array}$ & $\begin{array}{c}0.636 * * * \\
(65.147)\end{array}$ & $\begin{array}{c}0.275^{* * *} \\
(31.579)\end{array}$ & $\begin{array}{c}0.376^{* * * *} \\
(44.300)\end{array}$ & $\begin{array}{c}0.187 * * * \\
(40.261)\end{array}$ \\
\hline Greece & $\begin{array}{c}-0.172 * * * \\
(-9.617)\end{array}$ & $\begin{array}{c}0.094 * * * \\
(8.926) \\
\end{array}$ & $\begin{array}{c}0.550 * * * \\
(26.813) \\
\end{array}$ & $\begin{array}{c}-0.052 * * * \\
(-4.261)\end{array}$ & $\begin{array}{c}0.166^{* * * *} \\
(13.516)\end{array}$ & $\begin{array}{r}0.223 * * * \\
(31.750) \\
\end{array}$ \\
\hline Spain & $\begin{array}{c}0.331 * * * \\
(12.764)\end{array}$ & $\begin{array}{c}0.087 * * * \\
(4.257)\end{array}$ & $\begin{array}{l}0.780 * * * \\
(108.944)\end{array}$ & $\begin{array}{c}0.105 * * * \\
(6.568) \\
\end{array}$ & $\begin{array}{l}0.662 * * * \\
(152.983)\end{array}$ & $\begin{array}{c}0.146^{* * * *} \\
(27.040) \\
\end{array}$ \\
\hline France & $\begin{array}{c}0.553 * * * \\
(27.928)\end{array}$ & $\begin{array}{c}0.078 * * * \\
(19.303)\end{array}$ & $\begin{array}{c}0.784 * * * \\
(41.159)\end{array}$ & $\begin{array}{c}0.230 * * * \\
(20.229)\end{array}$ & $\begin{array}{c}0.391 * * * \\
(55.585)\end{array}$ & $\begin{array}{c}0.182 * * * \\
(42.290)\end{array}$ \\
\hline Italy & $\begin{array}{c}0.052 * * * \\
(3.591)\end{array}$ & $\begin{array}{c}0.120 * * * \\
(13.759)\end{array}$ & $\begin{array}{c}0.662 * * * \\
(48.849)\end{array}$ & $\begin{array}{c}0.063 * * * \\
(4.350)\end{array}$ & $\begin{array}{l}0.554 * * * \\
(128.018)\end{array}$ & $\begin{array}{c}0.036^{* * * *} \\
(7.077)\end{array}$ \\
\hline Austria & $\begin{array}{c}0.316^{* * *} \\
(56.711)\end{array}$ & $\begin{array}{c}0.105 * * * \\
(2.947)\end{array}$ & $\begin{array}{c}0.695^{* * *} * \\
(75.420)\end{array}$ & $\begin{array}{c}0.245 * * * \\
(23.008)\end{array}$ & $\begin{array}{c}0.388 * * * \\
(42.893)\end{array}$ & $\begin{array}{c}0.221 * * * \\
(27.931)\end{array}$ \\
\hline Portugal & $\begin{array}{c}0.028 * * * \\
(2.274)\end{array}$ & $\begin{array}{c}-0.038^{* * * *} \\
(-6.994)\end{array}$ & $\begin{array}{c}0.572 * * * \\
(47.505)\end{array}$ & $\begin{array}{c}0.015 \\
(1.238) \\
\end{array}$ & $\begin{array}{c}0.531 * * * \\
(82.379)\end{array}$ & $\begin{array}{c}0.081^{* * * *} \\
(13.288)\end{array}$ \\
\hline Finland & $\begin{array}{c}0.311 * * * \\
(27.228)\end{array}$ & $\begin{array}{c}0.031 * * * \\
(4.373)\end{array}$ & $\begin{array}{c}0.685^{* * *} \\
(46.041) \\
\end{array}$ & $\begin{array}{c}0.193 * * * \\
(9.095)\end{array}$ & $\begin{array}{c}0.609 * * * \\
(88.913)\end{array}$ & $\begin{array}{r}0.215^{* * *} \\
(50.912) \\
\end{array}$ \\
\hline
\end{tabular}

Note: This table shows the estimation results of Equation (2) for each lending rate using the PL approach before the Crisis (BC) and after the crisis (AC). Values in parentheses are $t$-statistics. $(* * *)$ indicates significance at the $1 \%$ level.

When considering deposit rates (Table 7), it is clear that the crisis has a significant impact on household deposit rates with agreed maturity, because the degree of pass-through to this rate declined sharply after the crisis for all countries of the Eurozone to achieve low levels of pass-through while the pass-through was very high and even complete before the crisis for several countries (Spain, Austria, Portugal and Finland).

Finally, the transmission from EONIA to overnight rate on deposits from NFCs is the highest among deposit rates analyzed in this paper both before and after the crisis. The financial crisis has a significant impact on the long-term pass-through because the degree of transmission declined after September 2008 for most countries in the euro area. 
Table 7. Pre- and post-crisis estimation results of the estimation of pass-through from MMR to deposit rates using the PL approach

\begin{tabular}{|c|c|c|c|c|c|c|}
\hline \multirow[t]{2}{*}{ Countries } & \multicolumn{2}{|c|}{$\begin{array}{c}\text { Deposit rate with agreed } \\
\text { maturity of household }\end{array}$} & \multicolumn{2}{|c|}{$\begin{array}{l}\text { Overnight deposit } \\
\text { rate of household }\end{array}$} & \multicolumn{2}{|c|}{$\begin{array}{l}\text { Overnight deposit } \\
\text { rate of NFC }\end{array}$} \\
\hline & BC & AC & BC & AC & BC & AC \\
\hline Euro Zone & $\begin{array}{l}\mathbf{1 . 0 0 0} * * * \\
(157.309)\end{array}$ & $\begin{array}{c}0.154 * * * \\
(11.575)\end{array}$ & $\begin{array}{l}0.744 * * * \\
(81.911)\end{array}$ & $\begin{array}{l}0.273 * * * \\
(74.247) \\
\end{array}$ & $\begin{array}{l}1.139 * * * \\
(123.166)\end{array}$ & $\begin{array}{r}0.322 * * * \\
(70.041) \\
\end{array}$ \\
\hline Germany & $\begin{array}{l}0.978 * * * \\
(102.450)\end{array}$ & $\begin{array}{c}0.356^{* * *} \\
(20.956)\end{array}$ & $\begin{array}{l}0.703 * * * \\
(100.416)\end{array}$ & $\begin{array}{l}0.331 * * * \\
(79.603)\end{array}$ & $\begin{array}{l}\mathbf{1 . 0 4 8}^{* * * *} \\
(93.029)\end{array}$ & $\begin{array}{r}0.577 * * * \\
(91.069)\end{array}$ \\
\hline Greece & $\begin{array}{c}0.870^{* * *} \\
(113.399)\end{array}$ & $\begin{array}{c}0.051^{* * *} * \\
(7.755)\end{array}$ & $\begin{array}{c}0.484 * * * \\
(42.378)\end{array}$ & $\begin{array}{c}0.175 * * * \\
(25.343) \\
\end{array}$ & $\begin{array}{c}0.933 * * * \\
(39.239)\end{array}$ & $\begin{array}{c}0.099 * * * \\
(8.402)\end{array}$ \\
\hline Spain & $\begin{array}{l}\mathbf{1 . 0 2 0}^{* * * *} \\
(99.292) \\
\end{array}$ & $\begin{array}{l}0.267 * * * \\
(21.545) \\
\end{array}$ & $\begin{array}{c}0.318 * * * \\
(11.067) \\
\end{array}$ & $\begin{array}{l}0.271 * * * \\
(34.201) \\
\end{array}$ & $\begin{array}{c}1.443 * * * \\
(87.149) \\
\end{array}$ & $\begin{array}{r}0.305^{* * *} \\
(30.695) \\
\end{array}$ \\
\hline France & $\begin{array}{l}0.868 * * * \\
(73.891) \\
\end{array}$ & $\begin{array}{c}0.153^{* * *} \\
(12.114) \\
\end{array}$ & $\begin{array}{l}0.533 * * * \\
(11.395) \\
\end{array}$ & $\begin{array}{l}0.167 * * * \\
(16.083)\end{array}$ & $\begin{array}{l}\mathbf{1 . 1 4 8}^{* * *} \\
(23.743)\end{array}$ & $\begin{array}{r}0.118 * * * \\
(18.722) \\
\end{array}$ \\
\hline Italy & $\begin{array}{c}0.848^{* * *} \\
(121.868) \\
\end{array}$ & $\begin{array}{c}0.026^{* * * *} \\
(1.839) \\
\end{array}$ & $\begin{array}{c}\mathbf{1 . 1 0 5}^{* * *} * \\
(98.051) \\
\end{array}$ & $\begin{array}{c}0.220 * * * \\
(36.299) \\
\end{array}$ & $\begin{array}{c}\mathbf{1 . 3 6 1} * * * \\
(89.971) \\
\end{array}$ & $\begin{array}{c}0.118 * * * \\
(17.160) \\
\end{array}$ \\
\hline Austria & $\begin{array}{c}\mathbf{1 . 0 0 2} * * * \\
(130.372) \\
\end{array}$ & $\begin{array}{c}0.483 * * * \\
(48.863) \\
\end{array}$ & $\begin{array}{l}\mathbf{1 . 0 8 2} * * * \\
(100.014) \\
\end{array}$ & $\begin{array}{c}0.316^{* * *} * \\
(38.507) \\
\end{array}$ & $\begin{array}{l}\mathbf{1 . 1 5 7 * * *} \\
(120.565) \\
\end{array}$ & $\begin{array}{c}0.479 * * * \\
(64.194)\end{array}$ \\
\hline Portugal & $\begin{array}{l}\mathbf{1 . 0 2 6}^{* * *} \\
(102.401)\end{array}$ & $\begin{array}{c}0.196^{* * *} \\
(15.722)\end{array}$ & $\begin{array}{c}0.389 * * * \\
(9.080)\end{array}$ & $\begin{array}{c}0.169 * * * \\
(8.433)\end{array}$ & $\begin{array}{c}\mathbf{1 . 3 7 5 * * *} \\
(27.935)\end{array}$ & $\begin{array}{r}0.475^{* * *} \\
(22.811) \\
\end{array}$ \\
\hline Finland & $\begin{array}{l}\text { 1.050*** } \\
(253.688)\end{array}$ & $\begin{array}{c}0.323 * * * \\
(30.439)\end{array}$ & $\begin{array}{l}\mathbf{1 . 3 8 6} * * * \\
(65.950)\end{array}$ & $\begin{array}{l}0.251 * * * \\
(32.367)\end{array}$ & $\begin{array}{l}\mathbf{1 . 5 8 9} * * * \\
(84.259)\end{array}$ & $\begin{array}{r}0.601 * * * \\
(67.006)\end{array}$ \\
\hline
\end{tabular}

Note: This table shows the estimation results of Equation (2) for each deposit rate before the Crisis (BC) and after the crisis (AC). Values in parentheses are the $t$-statistics. $(* * *)$ indicates significance at the $1 \%$ level. Values in bold represent full passthrough.

In general, the degree of pass-through is higher for deposit rates than for lending rates and the crisis led to a drop in transmission for all bank rates.

\section{CONCLUSION}

In this paper we examine the impact of the financial crisis on the degrees of long-term pass-through from rates derived from the money market (EONIA and 3-month Euribor) to lending and deposit rates of selected banks in the euro area countries. To this end, we use the Phillips and Loretan approaches which allows estimating the longrun pass-through.

The main findings of this study are summarized as follow. First, we find that the degree of adjustment of lending rates to 3-month Euribor rate is higher for interest rates on loans to NFCs. In addition, the comparison between degrees of long-run pass-through to deposit and lending rates leads to conclude that the deposit rates are more sensitive to variation in 3-month Euribor. Second, results obtained by the PL approach show that the degree of transmission is partial in all Euro countries. Third, we show that the financial crisis constitutes a break in the longrun pass-through from MMR to bank rates. Hence, our study is carried out in two subperiods namely before and after the financial crisis being defined by September 2008 Lehman Brothers bankruptcy.

Results given by the PL approach show that before the crisis, PL estimates of the degree of MMR transmission to consumer loans are high for most countries. After the crisis, PL estimates show that the evolution of the degree of pass-through is mixed, i.e. higher for some countries (Germany, Greece, Austria, Portugal and Finland) and lower for others (Spain, France and Italy). For rates on loans to NFCs, we show similar results as those for the previous rate before and after the.

Various courses of actions could be envisaged, such as taking into account the changes in rate-setting behavior following the turbulences in the money market through other approaches such as the Asymmetric TAR and MTAR cointegration models. 


\section{AUTHOR INFORMATION}

Manel Mansour is an assistant researcher at the University of Monastir, Tunisia. Her research focuses on the study of interest rate passthrough of Money market rate to retail rates.

David Heller is an assistant professor of finance at ISC Paris Business School, France. His research areas include Finance and Accounting.

Moez Labidi is a professor of economics at the University of Monastir, Tunisia. His research focuses on the study of monetary policy in emerging markets. He has published his recent articles in referred journals such as Economic Modelling and Journal of Applied Business Research.

Amine Lahiani is an associate professor of Economics at the University of Orléans, France. His research interests include the study of long memory models and threshold models. His published several papers in International Journal of Forecasting, Economic Modelling, Energy Economics, Energy Policy, Journal of International Financial Markets, Institutions \& Money.

\section{REFERENCES}

Abbassi, P., and Linzert, T., 2012, The effectiveness of monetary policy in steering money market rates during the recent financial crisis, Journal of Macroeconomics, 34, 945-954.

Aristei, D., and Gallo, M., 2012, Interest rate pass-through in the euro area during the financial crisis: A multivariate regime-switching approach, Quaderni Del Dipartimento Di Economia, Finanza E Statistica, Quaderno n. 107 October 2012.

Belke, A., Beckmann, J. and Verheyen, F., 2013, Interest Rate Pass-Through in the EMU - New Evidence from Nonlinear Cointegration Techniques for Fully Harmonized Data, Journal of international money and finance 37 (2013), pp 1- 24.

Blot, C. and Labondance, F., 2013, Business lending rate pass-through in the Eurozone : monetary policy transmission before and after the financial crash, Economics Bulletin, 2, 973-985.

Cecioni. M., Ferrero, G. and Secchi, A., 2011, Unconventional monetary policy in theory and in practice, Questioni di Economia e Finanza. Occasional Papers, n. 102. Bank of Italy. September.

Chow, g. (1960), Tests of Equality Between Sets of Coefficients in Two Linear Regressions, Econometrica, Vol. 28, n³, pp. 591-605.

Cihák, M., Harjes, T. and Stavev, E., 2009, Euro Area Monetary Policy in Uncharted Waters, IMF Working Paper, $09 / 185$.

Cordemans. N., and de Sola Perea. M, 2011, Central bank rates, market rates and retail bank rates in the euro area in the context of the recent crisis, Economic Review, 2011, I, p. $27-52$.

Cour-Thimann, P. and Winkler, B., The ECB's non-standard monetary policy measures, the role of institutional factors and financial structure, Working Paper Series, $N^{\circ} 1528$ / April 2013.

De Bondt, G., 2005, Retail bank interest rate pass-through: New evidence at the Euro area level, German Economic Review, 6, 37-78.

De Graeve, F., De Jonghe, O., Vander Vennet, R., 2004, The Determinants of Pass-Through of Market Conditions to Bank Retail Interest Rates in Belgium, National Bank of Belgium, Working Papers-Research Series (47).

De la Serre, A B., Frappa, S., Montornès, J and Murez, M., 2008, La transmission des taux de marché aux taux bancaires : Une estimation sur données individuelles françaises, Banque de France, NER - R \# 194, Janvier 2008.

Deutsche Bundesbank (2009), Short-Term Bank Lending Rates Since the Autumn of 2008, Monthly Report, Vol. 61, No. 5 , Frankfurt.

European Central Bank., 2009, Recent developments in the retail bank interest rates pass-through in the Euro area, Monthly Bulletin (August), pp 93-105.

Gambacorta, L. and Marques-Ibanez, D., 2011, The bank lending channel: Lessons from the crisis. Monetary and Economic Department BIS Working Papers No 345.

Gropp, R., Sørensen, C. and Lichtenberger, J., 2007, The Dynamics of Bank Spreads and Financial Structurell, ECB Working Paper Series, No. 714.

Harbo Hansen, N. and Welz, P., 2011, Interest Rate Pass-through During the Global Financial Crisis: The Case of Sweden, OECD Economics Department Working Papers, No. 855, OECD Publishing.

Jobst, C. and Kwapil, C., 2008, the interest rate pass-through in Austria - Effects of the Financial Crisis, Monetary Policy 
\& the Economy Q4/08.Karagiannis, S., Panagopoulos, Y. and Vlamis, P., 2010, Interest rate pass-through in Europe and the US: Monetary policy after the financial crisis, Journal of Policy Modeling 32(3), pp 323-338.

Liu, M-H., Margaritis, D. and Tourani-Rad, A., 2008, Monetary policy transparency and pass-through of retail interest rates, Journal of Banking \& Finance 32 (2008), pp 501-511

Nee Tai, P., Kun Sek, S. and Mun Har, W., 2012, Interest Rate Pass-Through and Monetary Transmission in Asia, International Journal of Economics and Finance Vol. 4, No. 2, February 2012, pp $163-174$.

Raunig, B. and Scharler, J., 2006, Money Market Uncertainty and Retail Interest Rate Fluctuations: A Cross-Country Comparison, Oesterreichische Nationalbank, Economic Studies Division, October 2006.

Ritz, R. A., 2010, How do banks respond to increased funding uncertainty?, Economics Series Working Papers 481, University of Oxford, Department of Economics.

Sander, H., Kleimeier, S., 2004, Convergence in European retail banking? What interest rate pass-through tells us about monetary policy transmission, competition and integration, Journal of International Money and Finance, 23, pp. $461-4$ 


\section{APPENDIX}

\section{Appendix A}

Table a.1. Correlation of consumption credit rates with Euribor 3 month

\begin{tabular}{|c|c|c|c|c|c|c|c|c|c|c|}
\hline & MMR & ZEURO & DE & GR & ES & FR & IT & $\mathbf{A T}$ & PT & FI \\
\hline TMM & 1 & & & & & & & & & \\
\hline ZEURO & 0.820 & 1 & & & & & & & & \\
\hline $\mathrm{DE}$ & 0.617 & 0.774 & 1 & & & & & & & \\
\hline GR & -0.094 & -0.248 & -0.378 & 1 & & & & & & \\
\hline ES & 0.603 & 0.900 & 0.595 & -0.318 & 1 & & & & & \\
\hline FR & 0.413 & 0.529 & 0.190 & -0.160 & 0.616 & 1 & & & & \\
\hline IT & 0.729 & 0.887 & 0.681 & -0.096 & 0.761 & 0.179 & 1 & & & \\
\hline AT & 0.922 & 0.786 & 0.601 & -0.067 & 0.618 & 0.578 & 0.597 & 1 & & \\
\hline $\mathrm{PT}$ & 0.277 & -0.015 & 0.309 & 0.075 & -0.178 & -0.171 & -0.047 & 0.357 & 1 & \\
\hline FI & 0.864 & 0.688 & 0.697 & -0.053 & 0.448 & 0.307 & 0.590 & 0.877 & 0.561 & 1 \\
\hline
\end{tabular}

Table a.2. Correlation of mortgage credit rates with Euribor 3 month

\begin{tabular}{|c|c|c|c|c|c|c|c|c|c|c|}
\hline & MMR & ZEURO & DE & GR & ES & FR & IT & AT & PT & FI \\
\hline TMM & 1 & & & & & & & & & \\
\hline ZEURO & 0.959 & 1 & & & & & & & & \\
\hline $\mathrm{DE}$ & 0.980 & 0.946 & 1 & & & & & & & \\
\hline GR & 0.854 & 0.810 & 0.879 & 1 & & & & & & \\
\hline ES & 0.915 & 0.987 & 0.891 & 0.753 & 1 & & & & & \\
\hline FR & 0.867 & 0.915 & 0.888 & 0.819 & 0.898 & 1 & & & & \\
\hline IT & 0.862 & 0.939 & 0.842 & 0.653 & 0.947 & 0.777 & 1 & & & \\
\hline AT & 0.944 & 0.925 & 0.977 & 0.847 & 0.870 & 0.916 & 0.823 & 1 & & \\
\hline PT & 0.801 & 0.899 & 0.773 & 0.705 & 0.923 & 0.749 & 0.932 & 0.726 & 1 & \\
\hline FI & 0.989 & 0.973 & 0.978 & 0.833 & 0.932 & 0.863 & 0.894 & 0.949 & 0.828 & 1 \\
\hline
\end{tabular}

Table a.3. Correlation of NFC credit rates with Euribor 3 month

\begin{tabular}{|c|c|c|c|c|c|c|c|c|c|c|}
\hline & MMR & ZEURO & DE & GR & ES & FR & IT & AT & PT & FI \\
\hline TMM & 1 & & & & & & & & & \\
\hline ZEURO & 0.979 & 1 & & & & & & & & \\
\hline $\mathrm{DE}$ & 0.990 & 0.975 & 1 & & & & & & & \\
\hline GR & 0.052 & 0.231 & 0.054 & 1 & & & & & & \\
\hline ES & 0.907 & 0.968 & 0.898 & 0.412 & 1 & & & & & \\
\hline FR & 0.972 & 0.991 & 0.965 & 0.240 & 0.960 & 1 & & & & \\
\hline IT & 0.876 & 0.943 & 0.857 & 0.447 & 0.961 & 0.931 & 1 & & & \\
\hline $\mathrm{AT}$ & 0.990 & 0.988 & 0.985 & 0.119 & 0.930 & 0.978 & 0.905 & 1 & & \\
\hline PT & 0.301 & 0.466 & 0.311 & 0.890 & 0.609 & 0.471 & 0.640 & 0.366 & 1 & \\
\hline FI & 0.977 & 0.982 & 0.967 & 0.147 & 0.936 & 0.975 & 0.913 & 0.983 & 0.378 & 1 \\
\hline
\end{tabular}

Table a.4: Correlation of deposit rate with agreed maturity of household with Euribor 3 month

\begin{tabular}{|c|c|c|c|c|c|c|c|c|c|c|}
\hline & MMR & ZEURO & DE & GR & ES & FR & IT & AT & PT & FI \\
\hline TMM & 1 & & & & & & & & & \\
\hline ZEURO & 0.760 & 1 & & & & & & & & \\
\hline $\mathrm{DE}$ & 0.984 & 0.833 & 1 & & & & & & & \\
\hline GR & 0.171 & 0.746 & 0.284 & 1 & & & & & & \\
\hline ES & 0.790 & 0.953 & 0.846 & 0.628 & 1 & & & & & \\
\hline FR & 0.944 & 0.899 & 0.971 & 0.435 & 0.879 & 1 & & & & \\
\hline IT & 0.416 & 0.809 & 0.515 & 0.862 & 0.662 & 0.642 & 1 & & & \\
\hline $\mathrm{AT}$ & 0.983 & 0.845 & 0.991 & 0.310 & 0.863 & 0.969 & 0.537 & 1 & & \\
\hline PT & 0.599 & 0.902 & 0.660 & 0.815 & 0.819 & 0.772 & 0.873 & 0.699 & 1 & \\
\hline FI & 0.969 & 0.874 & 0.982 & 0.369 & 0.882 & 0.983 & 0.557 & 0.984 & 0.733 & 1 \\
\hline
\end{tabular}


Table a.5: Correlation of overnight deposit rate of household with EONIA

\begin{tabular}{|c|c|c|c|c|c|c|c|c|c|c|}
\hline & MMR & ZEURO & DE & GR & ES & FR & IT & $\mathbf{A T}$ & PT & FI \\
\hline TMM & 1 & & & & & & & & & \\
\hline ZEURO & 0.955 & 1 & & & & & & & & \\
\hline DE & 0.945 & 0.991 & 1 & & & & & & & \\
\hline GR & 0.966 & 0.956 & 0.945 & 1 & & & & & & \\
\hline ES & 0.843 & 0.861 & 0.826 & 0.875 & 1 & & & & & \\
\hline FR & 0.811 & 0.814 & 0.851 & 0.820 & 0.564 & 1 & & & & \\
\hline IT & 0.942 & 0.981 & 0.956 & 0.939 & 0.810 & 0.782 & 1 & & & \\
\hline AT & 0.925 & 0.981 & 0.980 & 0.910 & 0.760 & 0.834 & 0.975 & 1 & & \\
\hline PT & 0.846 & 0.848 & 0.804 & 0.875 & 0.913 & 0.519 & 0.837 & 0.756 & 1 & \\
\hline FI & 0.809 & 0.897 & 0.876 & 0.758 & 0.684 & 0.645 & 0.918 & 0.926 & 0.698 & 1 \\
\hline
\end{tabular}

Table a.6: Correlation of overnight deposit rate of NFC with EONIA

\begin{tabular}{|c|c|c|c|c|c|c|c|c|c|c|}
\hline & MMR & ZEURO & DE & GR & ES & FR & IT & $\mathbf{A T}$ & PT & FI \\
\hline TMM & 1 & & & & & & & & & \\
\hline ZEURO & 0.962 & 1 & & & & & & & & \\
\hline $\mathrm{DE}$ & 0.989 & 0.986 & 1 & & & & & & & \\
\hline GR & 0.927 & 0.974 & 0.952 & 1 & & & & & & \\
\hline ES & 0.864 & 0.963 & 0.917 & 0.935 & 1 & & & & & \\
\hline FR & 0.856 & 0.915 & 0.884 & 0.912 & 0.895 & 1 & & & & \\
\hline IT & 0.839 & 0.939 & 0.876 & 0.946 & 0.946 & 0.905 & 1 & & & \\
\hline AT & 0.969 & 0.996 & 0.991 & 0.967 & 0.951 & 0.903 & 0.920 & 1 & & \\
\hline $\mathrm{PT}$ & 0.942 & 0.980 & 0.958 & 0.953 & 0.948 & 0.883 & 0.944 & 0.974 & 1 & \\
\hline FI & 0.950 & 0.991 & 0.973 & 0.958 & 0.967 & 0.925 & 0.937 & 0.985 & 0.977 & 1 \\
\hline
\end{tabular}

